\title{
Quality's Impact on Food Development in China
}

\author{
Yang Xu, Feng Tan*, Xinyi Peng, Yukun Li \\ Beijing University of Agriculture, 102206, China
}

\begin{abstract}
Compare to common food, premium food is produced by high quality raw materials, and processed under highly controlled processing procedure. However, its excellent quality features did not assist with the local made premium food sales in China. Based on statistic data analysis, it is found out quality is not a single significant factor impact on high quality food development. The development of high quality food is also impacted by employment status, number of children in family, age and occupation of food buyers. Producing high quality good taste food, with clear target on effective consumer groups are development opportunities for premium food in China.
\end{abstract}

Keywords-food quality; premium food; development; statistic analysis.

\section{INTRODUCTION}

According to the quality level, foods can be grouped into general quality common food and high quality premium food. The meaning of premium can be summarized as something of high quality, higher than usual quality. The premium food needs to achieve higher quality than other common food, produced by high quality raw materials together with advanced technologies to complete the processing [1]. Making premium food is also a way for food manufacturers to differentiate their products and make the food as "top of the range" [2]. High price, rare in the market, safe, high ethical requirements, innovation and unique brand image are also main characteristics of premium food [3-4]. In developed countries, premium products manufactures are always willing to pay more to keep the raw materials under the ethical control. Besides, premium food can achieve good sales with their innovative content and packaging. Also premium consumers find brand image of premium food showing their pursuit of life [5].

\section{CURRENT SITUATION OF HIGH QUALITY FOOD}

Chinese consumers not only demand basic foods to satisfy their physical needs, but also desire premium foods to fulfil other needs, such as love, belongings and ethic etc. It is forecasted the market share of cheap foods will reduce in the future. This is not only because of changing on consumers' demands, but also driving by consumers' ethic believes. They do not believe low price food would be a solution of food poverty. Making cheap food means to have cheap raw materials and process under industrial production which can be potential risks to agricultural sustainability and the capacity of the land[6]. Chinese consumers' purchasing on imported premium foods has be increasing since 2008, but the market share of local made premium food has reduced, which mainly due to the food safety accidents and other food issues such as fake products[7-8].

\section{DEVELOPMENT OF HIGH QUALITY FOOD IN CHINA}

\section{A. Food categories}

In China, the most traditional high quality premium food categories are alcohol, tea, and drinks etc. From marketing's point of view, any category of food can be marketing as premium, such as chips, biscuits and snacks etc. However, except of a few brands of alcohol[9], there are none strong recognizable brands found from other food categories[10]. In many consumers' mind, they recognize organic foods and well made imported foods as premium food [11].

\section{B. Market situation}

Recently, more consumers know and welling to pay for high quality foods. Companies from areas such as European Union entered into Chinese market, the imported volume of foods increased significantly since 2008. However, there are problems existing in current local premium food market [8$11]$.

Firstly, low quality fake premium food. A lot of local manufacturers copy well-known premium food brands and make fake products of very poor quality, which make consumers loose trust on local made premium food.

Secondly, competition between imported and local premium food. Well made, standard, high quality imported premium food enters into Chinese market and occupied big market share.

Thirdly, dull distribution channels. Supermarkets are the main places where consumers purchasing the premium food from. The development of specialist stores and e-tailor is driving the innovative consumers to try different channels to gather premium food.

\section{Consumers' behaviors on buying high quality food}

The higher consumers' income is, the more willing for them to buy high quality premium food. Although male consumers are more concern about food safety issues than female consumers, $95 \%$ imported foods be bought by female consumers. Quality, safety and price are the main concerning points when consumer buying premium food [8$10]$.

\section{Methodology}

In order to find out relationship between consumers' statistics data and premium food development, 
questionnaires have been used to street interview Chinese consumers who have purchased premium food in the past in Beijing. 220 valid questionnaires have been used in analysis.

\section{RESUlT ANALYSIS}

Main results and analysis based on consumer statistics and cross tabulation can be seen as following.

\section{A. Consumer information statistics}

It can be seen from the following Table 1 the main statistics data of interviewees of the research. 113 consumers spend more than 451 Yuan/week on buying foods. Only 88 consumers think buying of premium food will help with sustainable development of Agriculture, farmer welfare etc, this shows the low ethic believe of the Chinese consumers. Although 123 consumers think it is important to buy premium food, but only 95 consumers buy premium food regularly. Fish and meat, fruit and vegetable, milk and egg are the three most frequently purchased premium food categories. It is different from literatures, although there are a few well-known premium alcohol brands can be found in China, only $4 \%$ consumers buy premium alcohol regularly. This is mainly due to its high price, people normally buy premium alcohol for gift giving, rather than self-consume.

TABLE I CONSUMER INFORMATION

\begin{tabular}{|c|c|c|c|c|c|}
\hline $\begin{array}{c}\text { Consumer } \\
\text { information }\end{array}$ & Groups & $\begin{array}{l}\text { NO. of } \\
\text { people }\end{array}$ & $\begin{array}{c}\text { Consumer } \\
\text { information }\end{array}$ & Groups & $\begin{array}{l}\text { NO. of } \\
\text { people }\end{array}$ \\
\hline Gender & Male & 96 & $\begin{array}{c}\text { Weekly spending } \\
\text { on Food/Yuan }\end{array}$ & $1-150$ & 13 \\
\hline- & Female & 124 & - & $151-300$ & 43 \\
\hline Age & 17 and under & 2 & - & $301-450$ & 51 \\
\hline- & $18-24$ & 54 & - & $451-600$ & 62 \\
\hline- & $25-34$ & 50 & - & $601-1000$ & 35 \\
\hline - & $35-44$ & 48 & - & $\begin{array}{c}1000 \text { and } \\
\text { above }\end{array}$ & 16 \\
\hline - & $45-54$ & 40 & $\begin{array}{l}\text { Distinguish } \\
\text { between } \\
\text { premium food } \\
\text { and common } \\
\text { food (Multiple } \\
\text { Choice) }\end{array}$ & Good taste & 97 \\
\hline- & $55-64$ & 19 & - & High quality & 167 \\
\hline - & 65 and above & 7 & - & Good nutrition & 64 \\
\hline Occupation & Administrator & 24 & - & $\begin{array}{l}\text { Fine raw } \\
\text { materials }\end{array}$ & 42 \\
\hline - & Managerial & 26 & - & $\begin{array}{c}\text { Excellent } \\
\text { processing }\end{array}$ & 62 \\
\hline- & Professional & 84 & - & High price & 110 \\
\hline - & Student & 64 & - & Place of origin & 31 \\
\hline - & Lay off & 2 & \begin{tabular}{|} 
Buying premium \\
food can help \\
with the \\
sustainable \\
development of \\
Agriculture, \\
farmer welfare \\
etc.
\end{tabular} & Agree & 88 \\
\hline- & Retired & 20 & - & Disagree & 48 \\
\hline $\begin{array}{c}\text { No. of adults at } \\
\text { home }\end{array}$ & 1 & 58 & - & Difficult to say & 84 \\
\hline - & 2 & 116 & $\begin{array}{c}\text { Importance of } \\
\text { buying premium } \\
\text { food }\end{array}$ & Important & 123 \\
\hline - & 3 & 31 & - & \begin{tabular}{|c|} 
Neither \\
important nor \\
not important
\end{tabular} & 77 \\
\hline- & 4 & 10 & - & Not important & 20 \\
\hline - & 5 and above & 5 & \begin{tabular}{|c|} 
Regular buying \\
of premium food
\end{tabular} & Yes & 95 \\
\hline
\end{tabular}

\begin{tabular}{|c|c|c|c|c|c|}
\hline $\begin{array}{c}\text { No. of children } \\
\text { at home }\end{array}$ & 0 & 133 & - & No & 125 \\
\hline & 1 & 73 & $\begin{array}{c}\text { Category of } \\
\text { premium food } \\
\text { regularly be } \\
\text { bought (multiple } \\
\text { choice) }\end{array}$ & $\begin{array}{c}\text { Fruit and } \\
\text { vegetable }\end{array}$ & 112 \\
\hline- & 2 & 14 & - & Fish and meat & 123 \\
\hline- & 3 and above & 0 & - & Bakery & 75 \\
\hline- & - & - & - & Milk and egg & 95 \\
\hline- & - & - & - & Frozen food & 29 \\
\hline- & - & - & - & Snack & 20 \\
\hline- & - & - & - & Drink & 31 \\
\hline- & - & - & - & Alcohol & 9 \\
\hline
\end{tabular}

D. Relationship between consumer statistics and premium food purchasing

Employment status, age, number of children and occupation of consumers have strong relationship with premium food purchase.

Relationship between employment and purchasing of premium food. It can be seen from the following Figure 1 and 2 that employed consumers concern it is more importance of buying premium food and they do purchase more than two times regularly than unemployed consumers.

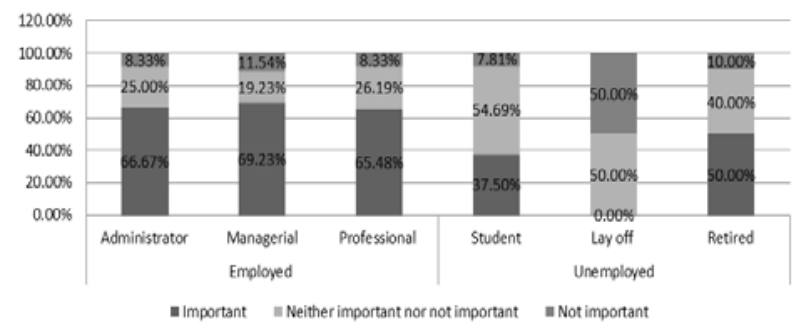

Figure 1. Employment and importance of buying premium food

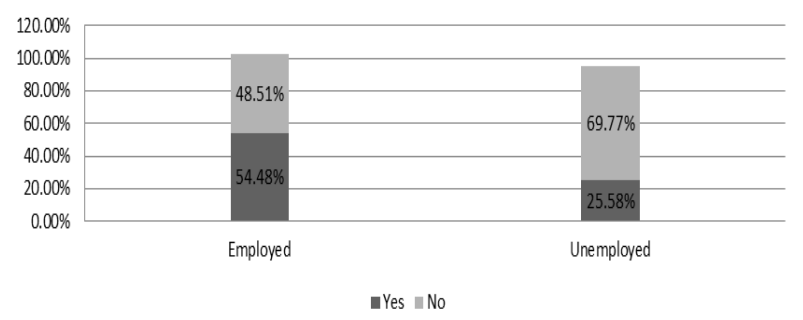

Figure 2. Employment and regular buying of premium food

Relationship between age and purchasing of premium food. Averagely, quality, price and taste are the three main factors consumers used to distinguish premium food to common food from most age groups. Consumers whose age above 55 years old do not think premium food is different from common food on raw materials, processing and place of origin. Consumers' age between 25-44 years old buy premium food more regularly than other age groups (Figure 3) 


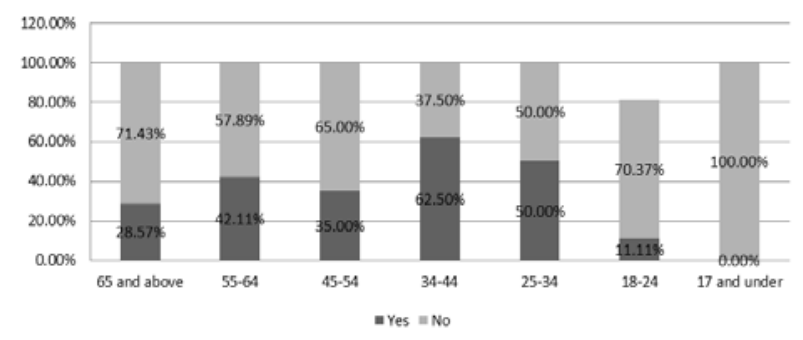

Figure 3. Age and regular buying of premium food

Relationship between number of children in family and purchasing of premium food. The number of children in family strongly influence the consumers' buying of premium food. Compare to no child families, consumers who have children nearly three times more regularly purchasing premium food (Figure 4).

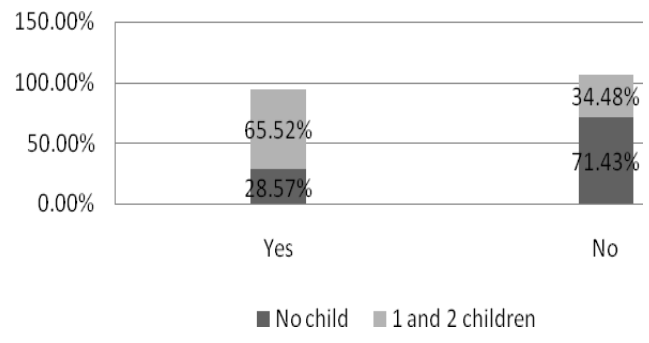

Figure 4. No. of children and regular buying of premium food

Relationship between occupation and purchasing of premium food. Very obviously, professional staffs are more willing to purchase premium food regularly compare to other employed consumers (Figure 5).

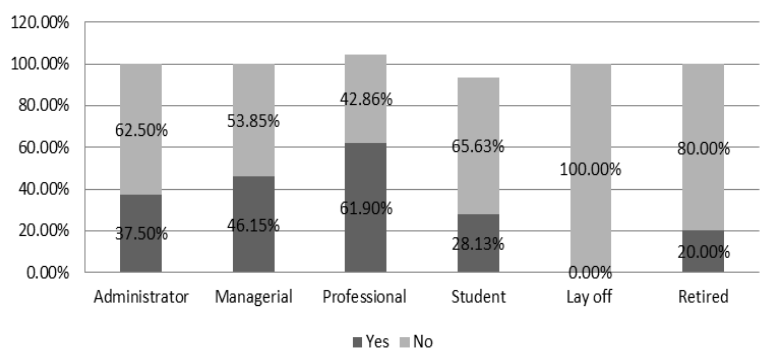

Figure 5. Occupation and regular buying of premium food

\section{CONCLUSION AND RECOMMENDATIONS}

Employment status, age, number of children in family and occupation are the main factors that influence on consumers' buying of premium food and so impact premium food's development in China. Consumers who have a job, especially professional staffs would like to purchase premium food more regularly. About 71\% none children families do not buy premium food regularly. Consumers age between 25-44 years old like to buy premium food more than other age groups. This is also partly because many consumers in this age group have children in family. The major differences between premium food and common food are high quality, high price and good taste. Fish and meat, fruit and vegetable, milk and egg are the three most frequently purchased premium food categories. Only $40 \%$ consumers think buying of premium food will help with sustainable development of Agriculture, farmer welfare etc. $55.9 \%$ interviewees think it is important to buy premium food, however, only $43.2 \%$ consumers buy it regularly.

Therefore, the high quality is not a single significant factor impacts on high quality food development. Premium food manufacturers and marketers need to pay attention to consumers who have children, age between 25-44 years old, work professionally, and have high income. Also, they need to emphasize on producing high quality and good taste premium food. Of course, it is also a potential risk for companies only to target the most profitable group of consumers and ignore others. Therefore, they need to understand their products features and the company strategies in order to make wise decisions.

\section{REFERENCES}

[1] Early, R. Food lecturer warns cheap food prices cannot continue. [On-line] Harper Adams University. Available at: http: //www.harper-adams.ac.uk/news/202152/food-lecturer-warns-cheapfood, -prices-cannot-continue, 2014.

[2] Escalas, J. Imagine yourself in the product: Mental simulation, narrative transportation, and persuasion. Journal of Advertising, 33(2), pp. 37-48, 2004.

[3] Food Empowerment Project, Ethical Food ChoicesSeleccionesÉticas de Alimentos - Food Empowerment Project. [On-line] Food Empowerment Project. Available at: http://www.foodispower.org/ethical-food-choices/, 2013.

[4] Food Navigator.com, High quality ingredients define premium food product. [On-line] Available at:http://www.foodnavigator.com/Market-Trends/High-qualityingredients-define- premium-food-product, 2014.

[5] Food standard agency, CRITERIA FOR THE USE OF THE TERMS FRESH, PURE, NATURAL ETC. IN FOOD LABELLING. 1st ed. [ebook] Food standard agency, pp.1-95. Available at:http://multimedia.food.gov.uk/multimedia/pdfs/markcritguidance.p df, 2008.

[6] Frozen, Convenience Foods - "Premium" No Longer Leads. [On-line] Available at: http:// www. frozenfoodeurope.com/article/reports/convenience-foods\%E2\%80\%9 Cpremium\%E2\%80\%9D-no-longer-leads, 2012.

[7] Ldoceonline.com. Longman English Dictionary Online. [On-line] Available at: http://www.ldoceonline.com/, 2014.

[8] Li Q. 2013 Study on premium food consumption and formats. Chinese business,(3),pp.341,2013.

[9] Tao, D. What is the solution of premium food. China Food Newspaper ,2014.

[10] Ye W.T. The EU emergency attack Chinese premium food market. Farm Produce Market Weekly,(22), pp.37,2009.

[11] Zhang J, Liu X.L, Wang.Y. Study on food industry premium brand marketing based on food safety. Northern economy and trade,(6), pp.48-49,2014. 